\title{
Ontogeny of Endothelins-1 and -3, Their Receptors, and Endothelin Converting Enzyme-1 in the Early Human Embryo
}

\author{
Marcus Brand, ${ }^{\star}$ Jean-Michel Le Moullec, ${ }^{*}$ Pierre Corvol, ${ }^{\ddagger}$ and Jean-Marie Gasc* \\ *Collège de France, INSERM U36, 75005 Paris, France; and ${ }^{\ddagger}$ ROUSSEL-UCLAF, 93235 Romainville Cedex, France
}

\begin{abstract}
The targeted gene inactivation of endothelins-1 and -3 (ET-1 and ET-3) and of one of their receptors, $\mathrm{ET}_{\mathrm{B}}$, in the mouse causes severe defects in the embryonic development. These defects, cardiovascular and craniofacial malformations for ET-1, and colonic agangliogenesis associated with skin pigmentation anomalies for ET-3 and the $\mathrm{ET}_{\mathrm{B}}$ receptor, reproduce pathological phenotypes due to natural mutations of the same genes in the mouse and the human. The mutant phenotypes have been causatively linked to deficient migration/proliferation/differentiation of neural crest cells, i.e., neurocristopathies. To bring new insight about the exact roles of ETs in development and the involvement of neural crest cells in these processes, we have explored, by in situ hybridization, the ontogeny in the early human embryo of the ET system (ET-1 and ET-3, $\mathrm{ET}_{\mathrm{A}}$ and $\mathrm{ET}_{\mathrm{B}}$ receptors, $\mathrm{ET}$ converting enzyme-1). ET receptor mRNA expression in neural crest cells starts at $3 \mathrm{wk}$ of gestation and continues during the entire period studied (up to $6 \mathrm{wk}$ of gestation). During this period, $\mathrm{ET}_{\mathrm{A}}$ expression progressively spreads to undifferentiated mesodermal components of various structures and organs (head and axial skeleton, lateral and ventral subdermal mesoderm), whereas $\mathrm{ET}_{\mathrm{B}}$ expression remains more restricted to fewer differentiated cells (neural tube, sensory and sympathetic ganglia, endothelium). Some of these tissues and structures that express either one of the receptors do not appear to be of neural crest origin. In the digestive tract and the cardiovascular area, the present observations on the sources of ETs and their target cells in the young embryo provide the basis for a dynamic interpretation of the results of gene targeting of the mouse and the human phenotypes, and point to other possible roles of ETs in other ontogenetic processes. The results support the concept of local, rather than hormonal, interactions between the sources and targets of ETs during development. (J. Clin. Invest. 1998. 101:549-559.) Key words: neural crest • enteric nervous system • gestation • cardiovascular system • in situ hybridization
\end{abstract}

Address correspondence to Dr. Jean-Marie Gasc, Collège de France, 3 rue d'Ulm, 75005 Paris, France. Phone: 33-1-44-27-16-47; FAX: 331-44-27-16-91; E-mail: gasc@infobiogen.fr

Received for publication 30 April 1997 and accepted in revised form 2 December 1997.

J. Clin. Invest.

(C) The American Society for Clinical Investigation, Inc. 0021-9738/98/02/0549/11 \$2.00

Volume 101, Number 3, February 1998, 549-559

http://www.jci.org

\section{Introduction}

Endothelin $(\mathrm{ET})^{1}$ was discovered in 1988 by Yanagisawa (1) on the basis of its vasoconstrictive effect. ET-1 exerts a prolonged and intense vasoconstriction and remains to date the most potent vasoconstrictive agent. Two other isoforms, ET-2 and ET-3, were discovered later, which also display vasoactive properties. ETs are synthesized as precursors, big ETs which are converted into active ETs by endothelin converting enzymes (ECEs). The effects of the ETs are mediated by at least two distinct receptors, type $\mathrm{A}$ and $\mathrm{B}\left(\mathrm{ET}_{\mathrm{A}}\right.$ and $\left.\mathrm{ET}_{\mathrm{B}}\right)$, which bind ETs with different affinities. $\mathrm{ET}_{\mathrm{B}}$ binds all three ETs equally, whereas $\mathrm{ET}_{\mathrm{A}}$ binds ET-1 preferentially (for review see reference 2).

It was shown later that ETs have mitogenic properties and that this system could be involved in growth processes in vitro and in vivo (3). ETs have mitogenic effects on endothelial (4), mesangial (5), human ovarian carcinoma cells (6), in Chinese hamster ovary cells expressing the $\mathrm{ET}_{\mathrm{A}}$ receptor (7). It has also been shown that ET-3 has mitogenic effects on melanocyte precursors in culture $(8,9)$.

An unexpected role of the ET system in embryonic and fetal development has been discovered recently and appears to be essential for cardiovascular and neural crest (NC)-derived cell differentiation. The causative role played by the ET-3/ET system in the murine $\mathrm{l}^{\mathrm{s}}$ and $\mathrm{s}^{1}$ mutant phenotypes has been demonstrated by the targeted inactivation of the same genes (10-12). The same pathological phenotype is observed in Hirschsprung's disease, a neurocristopathy sometimes associated with ET-3/ET ${ }_{\mathrm{B}}$ mutations (13-18). Similarly, ET-1 mutant mice present phenotypes characterized by cardiovascular and craniofacial malformations $(19,20)$.

Considering the primordial role of ET in embryonic development, it is essential to study in detail the expression of the genes of the ET system during early phases of ontogenesis. These studies could help to solve issues such as the exact origin and target of ETs in mammalian embryos and fetus. Indeed, several lines of evidence point to NC cells and/or their derivatives as the prime targets for ETs in embryonic development: the identification of genetic defects of ET system genes in hereditary diseases previously suspected to be neurocristopathies, the reproduction of similar phenotypes by gene inactivation of ETs and the $\mathrm{ET}_{\mathrm{B}}$ receptor, the inability of enteric neuroblasts to normally colonize the hindgut of mice defective for the $\mathrm{ET}_{\mathrm{B}}$ ( $\mathrm{s}^{1}$ mutant mouse) and ET-3 ( $\mathrm{l}^{\mathrm{s}}$ mutant mouse) genes (21), and the mitogenic effect of ET-3 on melanoblast, i.e., $\mathrm{NC}$ cell, differentiation in culture $(8,9,22)$. However, very

1. Abbreviations used in this paper: ECE, endothelin converting enzyme; ET, endothelin; $\mathrm{ET}_{\mathrm{A}}$ and $\mathrm{ET}_{\mathrm{B}}$, type $\mathrm{A}$ and $\mathrm{B}$ receptors of endothelins; NC, neural crest; NT, neural tube. 
little is known about the exact origin and target cells of ETs in mammalian embryo and fetus $(19,20,23,24)$. For instance, it is not at all clear whether ET receptors are expressed in ganglionic cells or in mesenchymal cells, and in what part of the digestive tract, or from where comes the message necessary to the migration, colonization, arrest at their destination, and differentiation of the ganglionic cells whose absence in the colon characterizes Hirschsprung's disease. The source(s) of ETs, their actual participation and their mechanism of action (autocrine, paracrine, or hormone-like at distance) remain to be elucidated.

We have performed an extensive in situ hybridization study of ETs-1 and -3, ECE-1, and the two ET receptors which constitute the major components of the ET system, in the human embryo from stages 10 to 17 (21-44 d of gestation). This study in the human shows for the first time the early expression of the $\mathrm{ET}_{\mathrm{A}}$ and $\mathrm{ET}_{\mathrm{B}}$ receptors and directly confirms the possible involvement of ETs in early NC cell migration/proliferation/ differentiation. The results underline the teratogenic risks of ET antagonists during pregnancy.

\section{Methods}

The techniques for preparation of human embryo paraffin sections, probe labeling by in vitro transcription, and in situ hybridization used in these studies were described previously $(25,26)$. Only a brief account of these techniques and details about the cDNA used are given below and in Table I.
Human tissue. 16 human embryos from 3 to $6 \mathrm{wk}$ of gestational age (Carnegie stages 9-10 to 17) were obtained after legal abortion by Mifepristone (Hôpital Broussais, Paris, France). Written maternal consent was obtained after information about the research project was given and the abortion had been performed. INSERM and the ethics committee were informed about the entire research project. Embryos within the trophoblast were fixed in $4 \%$ paraformaldehyde in PBS, then dissected out of the trophoblast and postfixed for 8-20 h. The actual developmental stage of each embryo was established according to the Carnegie classification (27). After dehydration and embedding in paraplast, sagittal, transversal, or frontal serial sections were cut $(7 \mu \mathrm{m})$ and mounted on silanated slides.

Riboprobe transcription. All cDNAs used in this study were recloned by RT-PCR of placenta or umbilical cord total RNA, using the primers and conditions detailed in Table I. In vitro transcription was carried out in the presence of ${ }^{35} \mathrm{~S}-\mathrm{UTP}$ (Amersham, Les Ulis, France) and the respective RNA polymerase (Boehringer Mannheim, Mannheim, Germany) to generate the antisense and sense probes as shown in Table I. Riboprobes were purified by ammonium acetateethanol precipitation and dissolved in $100 \mu \mathrm{l}$ TE-DTT $(10 \mathrm{mM}$ Tris, $1 \mathrm{mM}$ EDTA, $20 \mathrm{mM}$ DTT). Starting from $100 \mu \mathrm{Ci}{ }^{35} \mathrm{~S}$-UTP and $\sim 1 \mu \mathrm{g}$ of cDNA, $80-90 \%$ of all radiolabeled UTP was recovered in the precipitate. The average transcription reaction yielded $1-2 \times 10^{6} \mathrm{cpm} / \mu \mathrm{l}$ probe. Labeled probes were diluted to $10-13 \times 10^{3} \mathrm{cpm} / \mu \mathrm{l}$ in a hybridization mixture containing $50 \%$ formamide, $2 \times \mathrm{SSC}(0.3 \mathrm{M} \mathrm{NaCl}$, $0.03 \mathrm{M} \mathrm{Na}$ citrate), $1 \mathrm{mg} / \mathrm{ml}$ salmon sperm DNA, $10 \%$ dextran sulfate, and $70 \mathrm{mM}$ DTT.

It was verified that there was no cross-hybridization for the ETs and ET receptor probes by specific labeling in transfected cells expressing either one of the cDNAs.

The ECE-1 probe used detects both the ECE-1a and ECE-1b

Table I. Origin of Riboprobes

\begin{tabular}{|c|c|c|c|c|c|}
\hline Probe & Source of RNA & $\begin{array}{c}\text { Original } \\
\text { sequence }\end{array}$ & Primer sequences for RT-PCR & $\begin{array}{l}\text { Subcloning } \\
\text { plasmids }\end{array}$ & $\begin{array}{l}\text { Labeling: } \\
\text { cleavage site } \\
\text { and RNA } \\
\text { polymerase }\end{array}$ \\
\hline $\mathrm{ET}_{\mathrm{A}}$ & Placenta & Hosoda et al. & $\begin{array}{l}\text { Sense: 5' CTT CTC GAG ATC GAT } \\
\text { ATG GAA ACC CTT TGC CTC AGG } \\
\text { GCA 3'; Reverse: 5' CTT CCG CGG } \\
\text { AAG CTT TCA GTT CAT GCT GTC } \\
\text { CTT ATG GCT GCT 3'. }\end{array}$ & pcDNA3 & $\begin{array}{l}\text { as: XhoI, Sp6 } \\
\text { ss: XbaI, T7 }\end{array}$ \\
\hline $\mathrm{ET}_{\mathrm{B}}$ & Placenta & Sakamoto et al. & $\begin{array}{l}\text { Sense: } 5^{\prime} \text { ATT CTC GAG GAT CCA } \\
\text { TGC AGC CGC CTC CAA GTC TGT GC } \\
3^{\prime} ; \text { Reverse: } 5^{\prime} \text { ATT TCT AGA } \\
\text { AGC TTT CAA GAT GAG CTG TAT } \\
\text { TTA TTA CTG } 3^{\prime} .\end{array}$ & pcDNA3 & $\begin{array}{l}\text { as: KpnI, Sp6 } \\
\text { ss: XbaI, T7 }\end{array}$ \\
\hline ET-1 & Umbilical cord & Itoh et al. & $\begin{array}{l}\text { Sense: 5' GCT AGC CCG GGA TGG } \\
\text { ATT ATT TGC TCA TGA TTT TC 3'; } \\
\text { Reverse: 5' GTC GAC CTC GAG } \\
\text { TCA CCA ARG TGC TCG GTT GTG } \\
\text { GGT 3'. }\end{array}$ & $\begin{array}{l}\text { pBluescript } \\
\text { II KS }\end{array}$ & $\begin{array}{l}\text { ss: KpnI, T3 } \\
\text { as: SacI, T7 }\end{array}$ \\
\hline ET-3 & Small intestine & Onda et al. & $\begin{array}{l}\text { Sense: 5' ACG GTG CCC TAT GGA } \\
\text { CTG TC 3'; Reverse: 5' AAT TTC } \\
\text { TCT GCC AAA ATC CC } 3^{\prime} .\end{array}$ & $\begin{array}{l}\text { pBluescript } \\
\text { II KS }\end{array}$ & $\begin{array}{l}\text { as: EcoRI, T3 } \\
\text { ss: HincII, T7 }\end{array}$ \\
\hline ECE-1a & Umbilical cord & Shimada et al. & $\begin{array}{l}\text { Sense: 5' TCC ATG GAC CCC ACG } \\
\text { GTG GAC CCC 3'; Reverse: 5' } \\
\text { AGG CGT TCA CCA TGG GCG GGG } \\
\text { TCA } 3^{\prime} .\end{array}$ & pCRII & $\begin{array}{l}\text { ss: XbaI, Sp6 } \\
\text { as: HindIII, } \\
\text { T7 }\end{array}$ \\
\hline
\end{tabular}

PCR amplification: $30-32$ cycles at $94^{\circ} \mathrm{C}$ (denaturation), $50^{\circ} \mathrm{C}$ (annealing), and $72^{\circ} \mathrm{C}$ (extension) for 1 min (except ET-1: $30 \mathrm{~s}$ ). as, Antisense; ss, sense probes for hybridization. cDNA sequences are from references 33-37. 
mRNAs equally since it corresponds to $100 \%$ identical sequences of the two isoforms (28)

In situ hybridization. The detailed protocol for in situ hybridization has been published recently (25). It includes a step of signal enhancement by microwave treatment of the sections and a digestion with proteinase $\mathrm{K}$. The hybridization of the sections was performed by covering the sections with $30 \mu \mathrm{l}$ of the hybridization mixture $(3-4 \times$ $10^{5} \mathrm{cpm} / \mathrm{section}$ ) and incubating them overnight in a humid chamber at $50^{\circ} \mathrm{C}$. The posthybridization washes included solutions of varying degrees of stringency (from $5 \times \mathrm{SSC}$ with $50 \%$ formamide at $55^{\circ} \mathrm{C}$ to $0.01 \times$ SSC at room temperature) and a digestion with RNase A (20 $\mathrm{mg} / \mathrm{ml}$; Sigma, Saint-Quentin, France). The slides were exposed on a Biomax MR film (Eastman Kodak, Rochester, NY) to obtain macroscopic autoradiographic pictures (1-3 d) and then were dipped into NTB2 liquid emulsion (Eastman Kodak). At the end of the exposure time (1-4 wk), the slides were photographically processed and stained with Toluidine blue. Sections were observed with either bright-field or dark-field illumination. As the number of embryos at each stage was not sufficient and the hybridization conditions were not always strictly comparable, notably the length and the specific radioactivity of the probes, no attempt was made at a quantification of the hybridization signals. The labeling intensity was compared only between structures and organs within a series of sections of the same embryo hybridized with the same probe. A structure was determined positive for a probe when its labeling was unambiguously above the background observed with the sense probe.

Immunostaining. At the end of the posthybridization washes, some slides were immunostained with an antibody to tyrosine hydroxylase (Institut Jaques Boy, Reims, France). The immunostaining protocol included a preincubation in a normal serum, an incubation in the primary antibody ( $\alpha$-tyrosine hydroxylase diluted 1:1,000, for 60-90 min), a biotinylated secondary antibody, the ABC-peroxidase complex (Vector Laboratories, Burlingame, CA), and DAB- $\mathrm{H}_{2} \mathrm{O}_{2}$ as a chromogen. After DAB incubation, slides were washed overnight in $50 \mathrm{mM}$ Tris, $\mathrm{pH}$ 7.6, and then dehydrated. The immunostained slides were then processed for autoradiography like the other slides.

\section{Results}

Human embryos of the fourth and fifth weeks of gestation are characterized by crucial developmental processes: beginning of NC cell emigration from the neural tube (NT), separation into the neurectodermal and mesectodermal lineages and migration toward their final destination, closure of the NT, extension of the somites, beginning of the curvature of the heart, and appearance of the first heart beats and blood flow through the aortic arches, the aorta, the umbilical and vitelline arteries, and veins. In situ hybridization was performed to identify, in the early human embryo, in which cells the ET system was expressed.

Stage 9-10. $\mathrm{ET}_{\mathrm{A}}$ receptor mRNA was detected in the anterior NT in two small symmetrical groups of cells at the junction of the neuroepithelium with the surface epithelium (Fig. 1, $A$ and $B$ ), the exact location of the NC. Parallel to but outside of the NT, a diffuse cluster of mesenchymal cells, and in apparent continuity with this cluster also the mesenchyme around the aorta, showed the $\mathrm{ET}_{\mathrm{A}}$ mRNA labeling (Fig. 1, $E$ and $F$ ). The lateral and dorsal sides of the pharyngeal epithelium, which will form the roof of the first branchial pouch, were also labeled for the $\mathrm{ET}_{\mathrm{A}}$ receptor (Fig. $1 \mathrm{E}$ ). This latter epithelium, ventrally further, and always in the anterior half of the embryo, the coelomic epithelium, which forms the dorsal mesocardium and the myocardium of the primitive heart tube, was positive for $\mathrm{ET}_{\mathrm{A}}$ receptor mRNA (Fig. $1 \mathrm{E}$ ). Caudally to the heart tube, cells positive for $\mathrm{ET}_{\mathrm{A}}$ were scarce in the $\mathrm{NC}$ and completely absent beyond somite 4 .

In the same stage 9-10 embryos, only a faint signal for $\mathrm{ET}_{\mathrm{B}}$ receptor mRNA was detectable in the NC cells within the neuroepithelium (Fig. 1, $C$ and $D$ ). There was no signal at all in the presomitic mesenchyme, although a clear hybridization signal was visible in the surface epithelium prolonging the neuroepithelium (not shown). $\mathrm{ET}_{\mathrm{B}}$ receptor mRNA was also shown in the wall of the foregut diverticulum but only on the lateral and ventral sides, contrary to the $\mathrm{ET}_{\mathrm{A}}$ which was detected in the lateral and dorsal parts. The thin layer of cells which forms the endocardium within the heart cavity and the wall between the bulbus cordis and the ventricle also showed a low expression level of $\mathrm{ET}_{\mathrm{B}}$ mRNA. In the caudal part of the embryo, the notochordal plate displays a clear hybridization signal for $\mathrm{ET}_{\mathrm{B}}$, restricted to an array of 5-10 cells, directly in contact with the floor plate of the NT (not shown).

Stage 10-11. Mesenchymal cells which express the $\mathrm{ET}_{\mathrm{A}}$ receptor mRNA were distributed around the NT in the whole cephalic region with a higher density of positive cells at the mid- and hindbrain than at the forebrain level (Fig. $1 G$ ). The branchial arteries were surrounded with $\mathrm{ET}_{\mathrm{A}}$ receptor positive cells (Fig. $1 G$ ). $\mathrm{ET}_{\mathrm{A}}$ receptor transcripts were also detected in the wall of the aorta (Fig. $1 \mathrm{I}$ ), and the myocardium in both the common ventricular and the atrial chambers of the heart (not shown). Along the NT, cells labeled for the $\mathrm{ET}_{\mathrm{A}}$ receptor mRNA were observed in continuous streaks emigrating from the point of NT closure and reaching the somites (Fig. 1, I and $K)$. Lateral to the NC cells, the outward layers of the somites, i.e., the dermatome, were labeled whereas the inner layers, i.e., the myotome and the sclerotome, were not (Fig. $1 K$ ). In the lateral prolongation of the somites, beneath the ectoderm, labeled cells were observed in the mesenchyme. Ventral to the $\mathrm{NC}$ clusters of $\mathrm{ET}_{\mathrm{A}}$ positive cells (Fig. $1 I$ ), other mesenchymal cells formed a continuous population reaching the aorta, whose walls harbor some labeled cells, and the mesonephros. No positive cells were observed in the vicinity of the foreguthindgut region of the digestive tube, the hepatic diverticulum, or the sinus venosus (Fig. $1 I$ ).

The pattern of $\mathrm{ET}_{\mathrm{B}}$ receptor mRNA expression at stage 1011 differed from that of $\mathrm{ET}_{\mathrm{A}}$. At cephalic level (Fig. $1 \mathrm{H}$ ), labeled cells were found within the neuroepithelium and they displayed an increasing gradient from the forebrain (almost no positive cells) up to the hindbrain (almost all cells within the NT labeled), with the exception of the floor plate, always devoid of labeled cells. More caudally, at the same site where $\mathrm{ET}_{\mathrm{A}}$ receptor $\mathrm{mRNA}$ was detected in NC cells leaving the NT (Fig. 1, $I$ and $K$ ), $\mathrm{ET}_{\mathrm{B}}$ receptor $\mathrm{mRNA}$ was also detected (Fig. 1, $J$ and $L$ ). Like $\mathrm{ET}_{\mathrm{A}}$ positive cells, $\mathrm{ET}_{\mathrm{B}}$ positive cells formed streaks of cells extending from the dorsal side of the NT to the somite, but unlike $\mathrm{ET}_{\mathrm{A}}$ positive cells, $\mathrm{ET}_{\mathrm{B}}$ cells were observed in great number in the mesenchyme between the somite and the NT but not between the somite, i.e., the dermatome, and the surface epithelium. Outside of the brain, isolated positive cells were present in small numbers in the vicinity of the otic vesicles, and in the mesenchyme around the branchial arteries (Fig. $1 H$ ). The epithelium of the pharyngeal cavity was not labeled. Along the digestive tube the most distinctive feature was the presence of cells which express $\mathrm{ET}_{\mathrm{B}}$ receptor mRNA in the mesenchyme around the digestive tube (Fig. $1 J$ ).

At stage 10-11, cells which expressed ET-1 mRNA were observed in the mesodermal component of the first branchial 

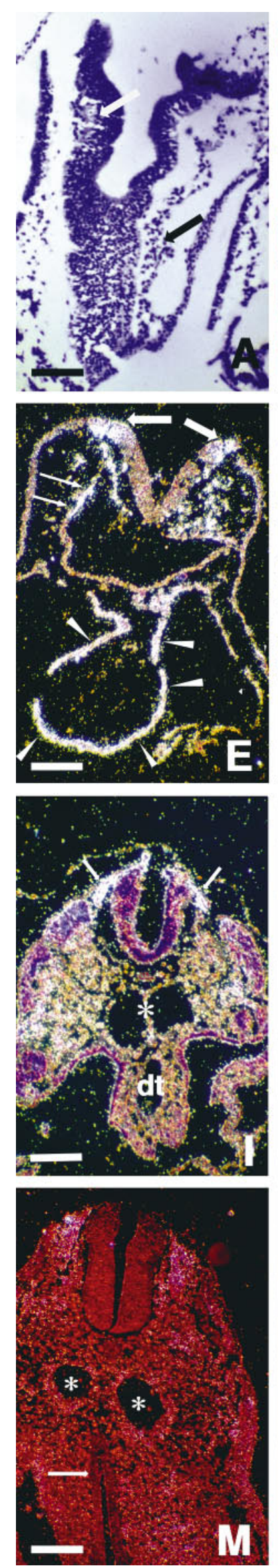
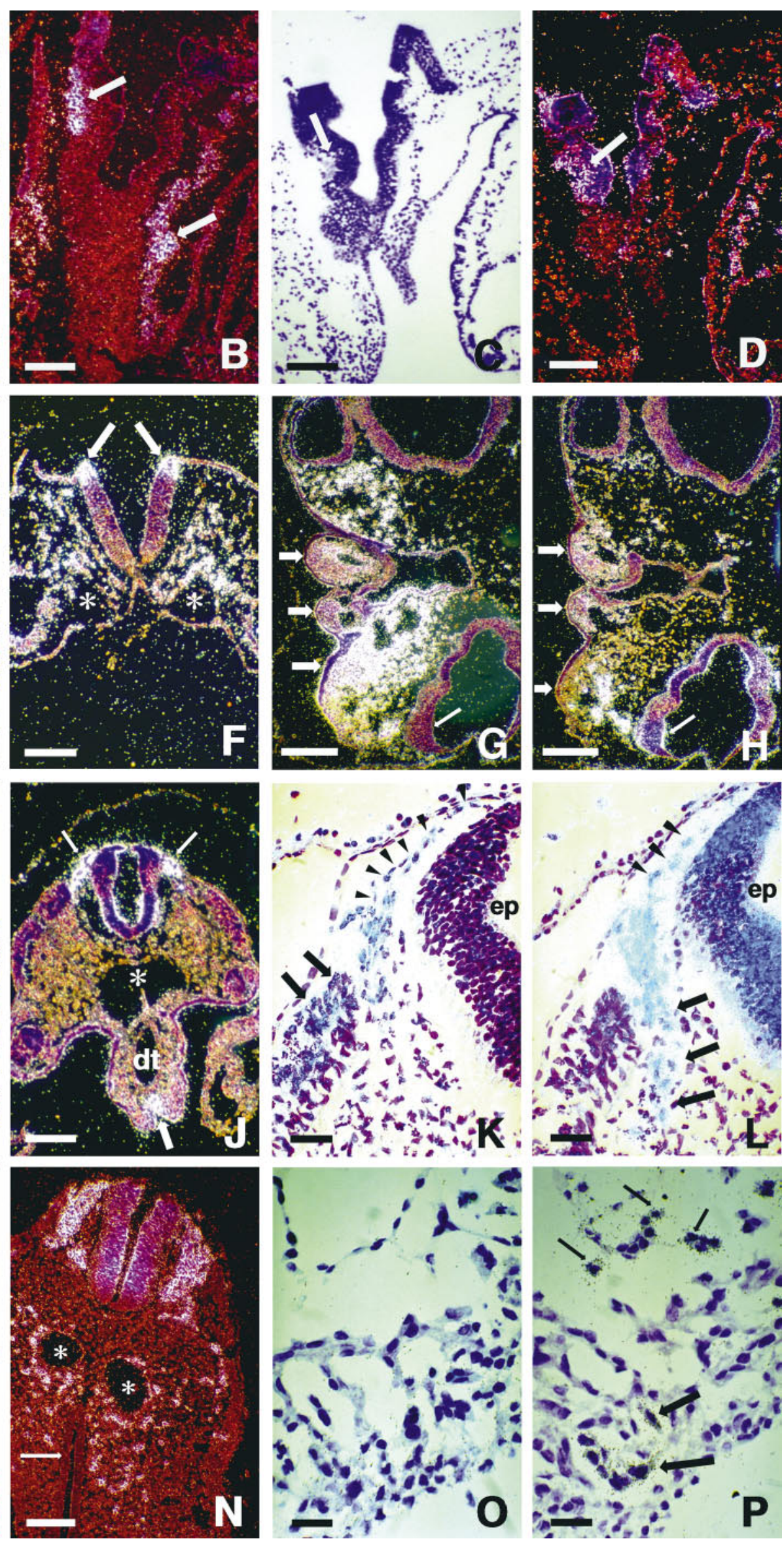

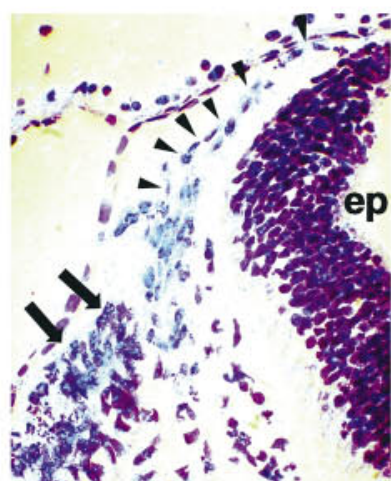

$a^{x^{x}} x^{x}$

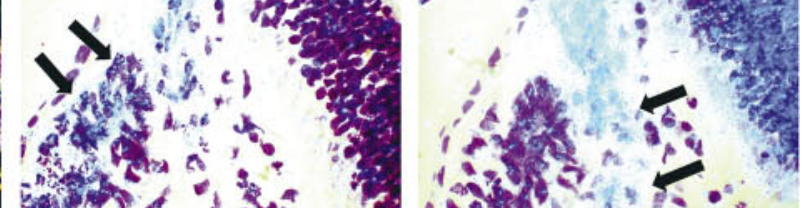

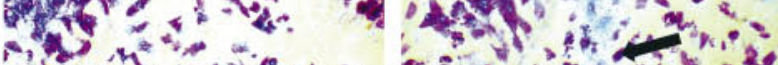
to

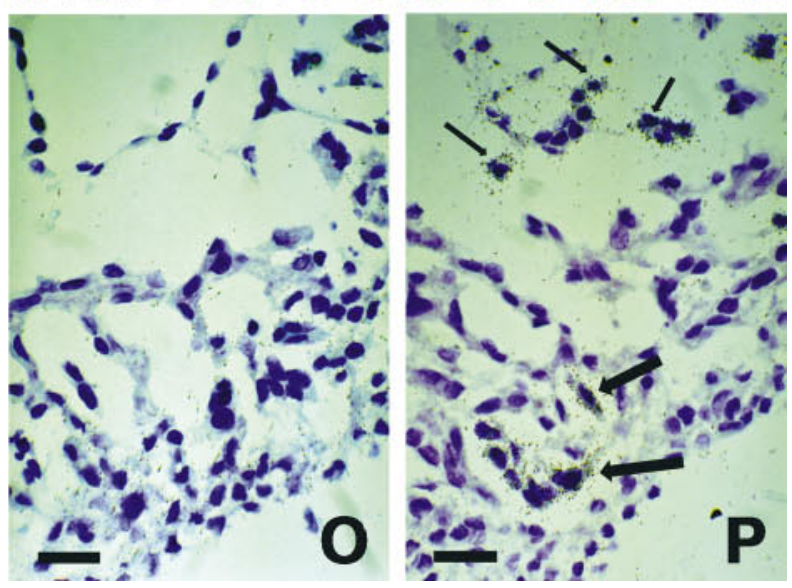


Table II. mRNA Expression of Components of the ET System (Stage 12 and 13 Human Embryos)

\begin{tabular}{|c|c|c|c|c|c|}
\hline & $\mathrm{ET}_{\mathrm{A}}$ & $\mathrm{ET}_{\mathrm{B}}$ & ET-1 & ET-3 & ECE-1 \\
\hline \multicolumn{6}{|l|}{ Axial structures: } \\
\hline NT & - & + & - & - & - \\
\hline Spinal ganglion & + & + & - & - & - \\
\hline Sympathetic ganglion & + & + & - & - & - \\
\hline Mesoderm & + & + & - & - & + \\
\hline Somites: dermatome, myotome & - & - & - & - & - \\
\hline sclerotome & - & + & - & - & - \\
\hline \multicolumn{6}{|l|}{ Branchial arches and heart: } \\
\hline Branchial arches: ectoderm & + & - & + & - & - \\
\hline mesoderm & + & + & + & - & + \\
\hline Heart: myocardium & + & - & - & - & - \\
\hline endocardium & - & + & + & - & + \\
\hline \multicolumn{6}{|l|}{ Large vessels (inflow, outflow } \\
\hline tract): VSMC & + & - & + & - & - \\
\hline endothelium & - & + & + & - & + \\
\hline \multicolumn{6}{|l|}{ Digestive tract: } \\
\hline Foregut mesoderm & + & - & - & - & - \\
\hline ganglion & - & + & - & - & - \\
\hline Hindgut mesoderm & - & - & - & + & - \\
\hline ganglion & - & - & - & - & - \\
\hline Liver: hepatocytes & - & - & - & - & + \\
\hline sinusoids & + & + & - & - & - \\
\hline Subepidermal mesenchyme & + & + & - & - & - \\
\hline
\end{tabular}

The + and - signs refer only to the presence or absence of hybridization signal clearly distinguishable from background labeling and do not suggest comparative quantitative data. See Tables III and IV for older embryos. VSMC, Vascular smooth muscle cells.

arch and in the endothelium of the sinus venosus, endocardial cushion, and aorta (not shown). No ET-3 mRNA could be detected at that stage.

Stages 12-13-14. The observations made on stage 12 and 13 embryos are summarized in Table II.

$\mathrm{ET}_{\mathrm{A}}$ receptor transcripts were still detected at cephalic level in the whole mesenchyme with a particularly high density of labeling around cephalic vesicles, the otic vesicles, and large blood vessels. At stage 13-14, cells within the cephalic ganglia, such as the fascioacoustic and trigeminal ganglia, were labeled.
$\mathrm{ET}_{\mathrm{A}}$ receptor transcripts were detected in mesenchymal cells of the branchial arches and around the pharyngeal region of the digestive tube whose epithelial layers were also positive. In the heart, the myocardium was labeled with a particularly high level of labeling observed in the myocytic layer of the outflow tract composed by the junction of the branchial arteries and the aortic sac. No $\mathrm{ET}_{\mathrm{A}}$ labeling was observed in the endocardium (Fig. $1 O$ ). A few labeled cells were seen in the mesenchyme closely lining the aorta (Figs. $1 M$ and $2 A$ ) and other large vessels such as the sinus venosus between the heart and the liver.

The trachea-brunchi and the pharynx-esophagus pass through the same $\mathrm{ET}_{\mathrm{A}}$ positive mesenchyme. The level of $\mathrm{ET}_{\mathrm{A}}$ receptor expression increases up to the entrance of the stomach and then decreases from the exit of the stomach to the duodenum, where only cells of dorsal and ventral mesenteries appear labeled. In the liver, the hepatocytes appear devoid of labeling, whereas the cells lining the hepatic islets were strongly $\mathrm{ET}_{\mathrm{A}}$ positive.

In the mesonephros, all epithelial structures, including the Wolffian duct, were negative for $\mathrm{ET}_{\mathrm{A}}$, whereas a few $\mathrm{ET}_{\mathrm{A}}$ positive mesenchymal cells were detected around the glomeruli. These $\mathrm{ET}_{\mathrm{A}}$ mRNA labeled mesenchymal cells appeared to form a continuous population of positive cells surrounding many differentiated structures and displaying various cell densities and labeling intensities (sclerotome, blood vessels, digestive tube, trachea).

The distribution of $\mathrm{ET}_{\mathrm{B}}$ receptor mRNA at stages 12-13-14 becomes more different than at earlier stages from that of $\mathrm{ET}_{\mathrm{A}}$ receptor at earlier stages. While $\mathrm{ET}_{\mathrm{A}}$ receptor $\mathrm{mRNA}$ tends to be expressed in most of the undifferentiated mesodermal and mesenchymal cells surrounding epithelial structures (Fig. 1M), in contrast $\mathrm{ET}_{\mathrm{B}}$ receptor mRNA (Fig. $1 \mathrm{~N}$ ) was expressed in a much more limited number of cells which belong to more defined cell types, like the NT, the ganglionic or endothelial cells. In the head, $\mathrm{ET}_{\mathrm{B}}$ mRNA expression is no more detectable in the forebrain whereas the mid- and hindbrain remain positive. The two largest ganglia in the hindbrain region (fascioacoustic and trigeminal) displayed a high intensity of labeling in most cells within the ganglion, while the surrounding mesenchyme was negative. Caudally, from thoracic to lumbosacral ganglia, cells positive for $\mathrm{ET}_{\mathrm{B}}$ formed a continuous chain which extended ventrolaterally along the internal aspect of the somites and then, further ventrally, toward the Wolffian duct and the

Figure 1. In situ hybridization detection of $\mathrm{ET}_{\mathrm{A}}$ and $\mathrm{ET}_{\mathrm{B}}$ receptor mRNAs in stage 9-10 $(A-F), 10-11(G-L)$, and $12(M-P)$ human embryos. At stage 9-10, $\mathrm{ET}_{\mathrm{A}}$ mRNA ( $A$ and $B$; slanting sections at midcephalic level) appears within the neuroepithelium at the site of $\mathrm{NC}$ cells (arrows); $\mathrm{ET}_{\mathrm{B}}$ mRNA $(C$ and $D)$ appears at the same location in fewer cells (arrows). At the level of the heart tube $\left(E\right.$, cross-section) cells positive for the $\mathrm{ET}_{\mathrm{A}}$ mRNA are observed at the junction between the neuro- and surface epithelium (thick arrows), in the presomitic mesenchyme, in the dorsal and lateral walls of the digestive tube (thin arrows), and in the myocardium (arrowheads). More caudally $(F), \mathrm{ET}_{\mathrm{A}} \mathrm{mRNA}$ positive cells are also found around the aorta (asterisks). At stage 10-11, at the level of the branchial arches $(G), \mathrm{ET}_{\mathrm{A}} \mathrm{mRNA}_{\mathrm{A}}$ is observed in the mesodermal tissue of the arches (thick arrows), whereas $\mathrm{ET}_{\mathrm{B}}$ mRNA positive cells $(H)$ are much fewer in the arches and mostly restricted to NC cells $($ thin arrows) and NT (top is cephalic anterior and bottom is cervical level of the brain). More caudally, $\mathrm{ET}_{\mathrm{A}}$ receptor mRNA $(I)$ is found in NC cells along the NT (thin arrows) and in most mesenchymal tissues, but not around the digestive tube $(d t)$, whereas $\mathrm{ET}_{\mathrm{B}}$ mRNA $(J)$ is mostly expressed in the NT and $\mathrm{NC}$ cells (thin arrows) and in few cells within the mesodermal component of the digestive tube (thick arrow). At a higher magnification, the strands of NC cells positive for $\mathrm{ET}_{\mathrm{A}}$ mRNA (K, arrowheads) appear to enter the dermatome (arrows) and are generally located more laterally than $\mathrm{ET}_{\mathrm{B}}$ mRNA receptor positive cells $(L)$ which are present mostly in the mesenchyme between the somite and the NT (arrows). At stage 12 while mesodermal cells appear slightly positive for $\mathrm{ET}_{\mathrm{A}}$ mRNA $(M)$ with a higher intensity around the aorta (asterisks) and NT, $\mathrm{ET}_{\mathrm{B}} \mathrm{mRNA}$ positive cells $(N)$ appear to form a continuous pathway from the NT to the pharyngeal diverticulum of the endoderm (arrow). At the same stage in the heart, a weak hybridization signal for $\mathrm{ET}_{\mathrm{A}}$ mRNA receptor $(O)$ was detected in the myocardium, whereas the $\mathrm{ET}_{\mathrm{B}}$ mRNA $(P)$ was present only in few cells lining the trabeculae (arrow). Bright-field: $A, C, K, L, O$, and $P$; dark-field: $B, D-J, M$, and $N$. Scale bars, $50 \mu \mathrm{m}$, except $K, L, O$, and $P, 10 \mu \mathrm{m}$. 

(1)

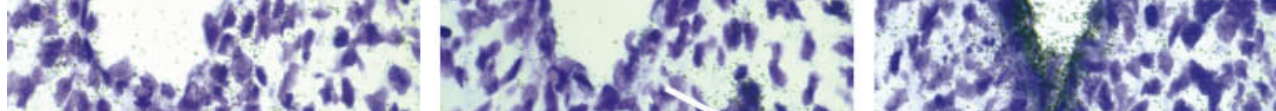

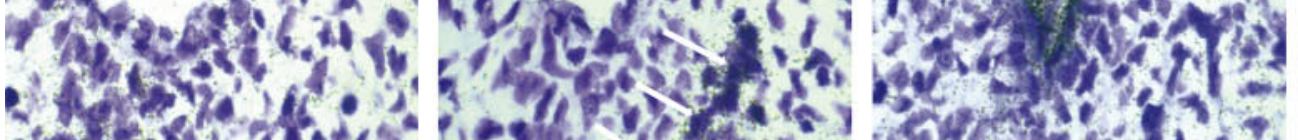

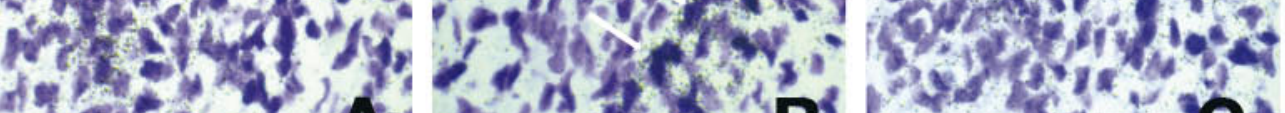

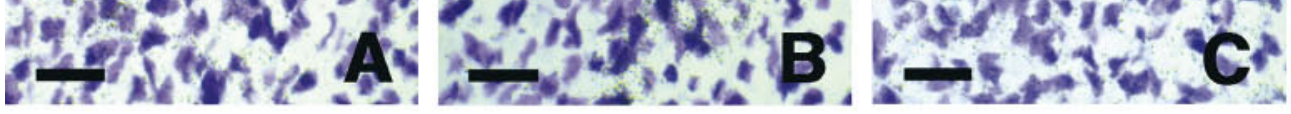
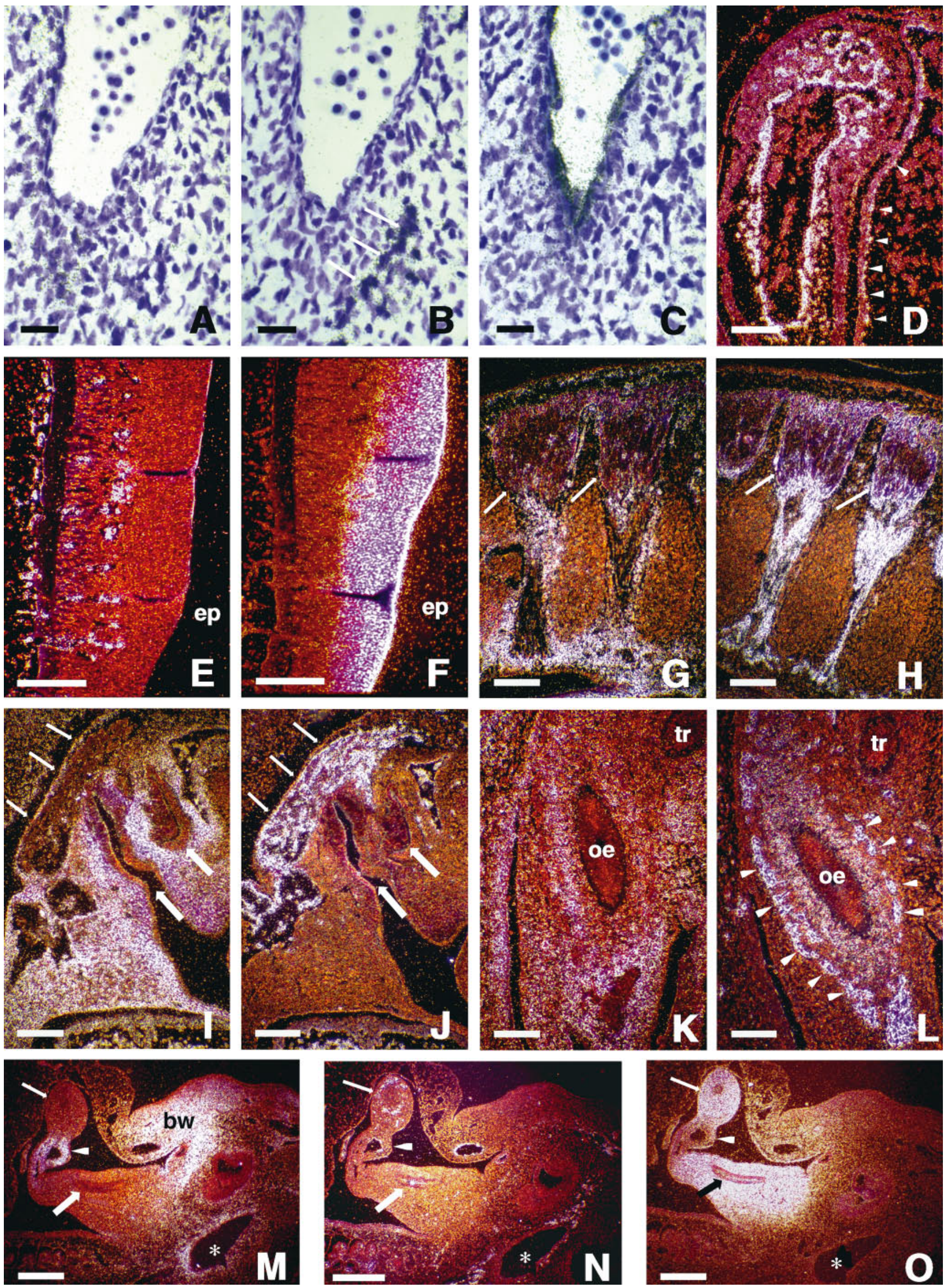
dorsal aorta (Figs. $1 \mathrm{~N}$ and $2 \mathrm{~B}$ ) where they constituted the chain of sympathetic ganglia. To summarize, the distribution of the cells which expressed $\mathrm{ET}_{\mathrm{B}}$ receptor mRNA constitute on each side of the embryo, from dorsal to ventral, a continuous longitudinal chain at the level of the NC, a segmented bed at the level of the somites, and strands of isolated cells when they reach the aorta. The somites were devoid of $\mathrm{ET}_{\mathrm{B}}$ mRNA expressing cells except for the strands of cells going across the sclerotome toward the aorta.

Mesenchymal cells scattered around branchial arches were labeled for $\mathrm{ET}_{\mathrm{B}}$ mRNA. However, at stage 13-14 there were few labeled cells and they were condensed near the center of the mesodermal component of arches 1 and 2. In the heart, $\mathrm{ET}_{\mathrm{B}}$ mRNA was detected in the endocardium of all chambers. The highest level of labeling was observed within the trabeculated wall of the common ventricular chamber (Fig. $1 P$ ).

In the digestive tract, $\mathrm{ET}_{\mathrm{B}}$ positive cells were detected within the mesodermal component of the pharynx and stomach, circling the gut epithelium at some distance. These cells were characterized as enteric neuron precursors by their tyrosine hydroxylase immunoreactivity. Contrasting with the esophagus, the trachea did not show any $\mathrm{ET}_{\mathrm{B}}$ positive cells within its mesoderm. Lower along the digestive tube, positive cells became less frequent. In the liver, as with $\mathrm{ET}_{\mathrm{A}}$ receptor mRNA, the $\mathrm{ET}_{\mathrm{B}}$ receptor mRNA was not detected in hepatocytes but rather in cells lining the hepatic islets. Whether these positive cells are the same as those positive for $\mathrm{ET}_{\mathrm{A}}$ could not be determined. In the mesonephros, the epithelium of the Wolffian duct and its collecting tubule diverticula showed a strong $\mathrm{ET}_{\mathrm{B}}$ hybridization signal whereas the proximal tubules and glomeruli were negative.

In stage 12-13-14 embryos, ET-1 mRNA expression could be detected in both the mesodermal and epithelial components of the branchial arches, in endothelial cells of all large vessels (Fig. $2 C$ ) and in the endocardial tissue of the heart. However, in the ventricles, cells of the trabeculae which were $\mathrm{ET}_{\mathrm{B}}$ mRNA positive were ET-1 mRNA negative.

ET-3 mRNA was detected as a weak hybridization signal in the mesodermal component of the digestive tube, hardly above background level in the pharyngeal region and esophagus, but clearly detectable from the stomach to the hindgut. A weak ET-3 signal was also observed in the mesoderm of the four limbs.
ECE-1 was not detected within the brain and NT, but several mesenchymal layers of cells that more or less condensed outside the NT either in the head or the rest of the body showed a high level of ECE-1 mRNA expression. The mesodermal component of the digestive tube was negative, whereas the same tissue surrounding the main bronchus was positive for ECE-1 mRNA. In the liver, hepatocytes expressed ECE-1 mRNA. In the heart, all endocardial cells were positive for ECE-1 at a level higher than at all other locations in the embryo, particularly in the endocardial cushion (Fig. $2 D$ ) and the endocardial cells of the trabeculated common chamber of the heart. The endothelium of all arteries was positive for ECE-1.

Human embryos of the fifth and sixth weeks are characterized by a profound remodeling and expansion of the vascularization, the formation of a four-chamber heart, elongation and specialization of the segments of the digestive tube, and differentiation of the sensory placodes. The observations made on stage 15-16-17 embryos are recapitulated in Tables III and IV. In the brain and $\mathrm{NT}, \mathrm{ET}_{\mathrm{A}}$ receptor mRNA was detected only in the walls of capillaries budding from extraneural vessels (Fig. $2 E$ ). ET $_{\mathrm{B}}$ receptor mRNA was still expressed with the same pattern as at previous stages (Fig. $2 F$ ) with a clear restriction of the signal to the ependymal layers. In cephalic and dorsal root ganglia and in nerves, only a few small mesenchymal cells were $\mathrm{ET}_{\mathrm{A}}$ positive in comparison to the more numerous cells positive for $\mathrm{ET}_{\mathrm{B}}$ receptor in the same ganglia (Fig. 2, $G$ and $H$ ). With both probes in these ganglia, typical neuronal cells showed no labeling. In contrast, in the sympathetic chain of ganglia typical neuronal cells, identified by their tyrosine hydroxylase immunoreactivity, were $\mathrm{ET}_{\mathrm{A}}$ negative and $\mathrm{ET}_{\mathrm{B}}$ positive (not shown). It is worth noting that the ganglionic cells displaying the strongest tyrosine hydroxylase immunostaining were $\mathrm{ET}_{\mathrm{B}}$ negative. A weak ET-3 labeling was also observed in the cervical superior ganglion, located dorsally to the aortic sac.

Almost all cells of the mesodermal component of the branchial arches were positive with the $\mathrm{ET}_{\mathrm{A}}$ probe (Fig. $2 \mathrm{I}$ ), while $\mathrm{ET}_{\mathrm{B}}$ was expressed only in a round, dense cluster of cells located within the mesoderm of arches 1 and 2 and in the cervical superior ganglia (Fig. $2 \mathrm{~J}$ ). ET-3 mRNA expression was detected in the mesodermal component of the branchial arches, whereas ET-1 mRNA was not detectable.

The results of our observations on the heart are recapitulated in Table IV. In summary, $\mathrm{ET}_{\mathrm{A}}$ receptor mRNA is ex-

Figure 2. Tissue distribution of $\mathrm{ET}_{\mathrm{A}}$ and $\mathrm{ET}_{\mathrm{B}}$ receptor mRNA shown by in situ hybridization in stage 12-13 $(A-D)$ and $16(E-O)$ human embryos. Along the aorta, $\mathrm{ET}_{\mathrm{A}}$ mRNA $(A)$ is expressed mostly in mesenchymal cells in the vicinity of the vessel $\mathrm{ET}_{\mathrm{B}} \mathrm{mRNA}(B)$ in a few ganglionic cells (thin arrows) and in endothelial cells (not visible), whereas ET-1 mRNA $(C)$ is detected in the layers of mesenchyme closest to the aorta and also in endothelial cells. In the heart, the endocardial cushion $(D)$ is lined with cells positive for ECE-1 mRNA. At stage 16, in the thoracic $\mathrm{NT}, \mathrm{ET}_{\mathrm{A}}$ mRNA $(E)$ is expressed only in the walls of the small capillaries which are formed by budding of the vascularization network outside of the NT, whereas $\mathrm{ET}_{\mathrm{B}}$ mRNA $(F)$ is detected along the ependymal canal (ep) and not in the outer layers of neural cells. At the same middorsal level but more laterally, $\mathrm{ET}_{\mathrm{A}}$ receptor mRNA $(G)$ is weakly expressed in mesenchymal cells around sclerotome and dorsal root ganglia (thin arrows), whereas $\mathrm{ET}_{\mathrm{B}}$ mRNA positive cells $(H)$ are found along the nerves and in nonneuronal cells within the dorsal root ganglia (thin arrows). In the posterior branchial arches, $\mathrm{ET}_{\mathrm{A}}$ mRNA $(I)$ is observed in all the mesodermal components surrounding the branchial epithelium (arrows), large vessels, and ganglia, whereas $\operatorname{ET}_{\mathrm{B}}$ mRNA $(J)$ is expressed mostly in the sympathetic ganglia (thin arrows). In the digestive tract at pharyngeal level, the mesenchymal tissue expresses $\operatorname{ET}_{\mathrm{A}}$ mRNA $(K)$ around esophagus $(o e)$ and trachea $(t r)$, whereas $\operatorname{ET}_{\mathrm{B}} \mathrm{mRNA}_{(L)}$ is expressed in the layers of mesenchymal cells closest to the digestive epithelium (oe) and not the trachea (tr), and in ganglionic cells (arrowheads) circling outward of the $\mathrm{ET}_{\mathrm{A}}$ mRNA positive cells. In the distal part of the digestive tube, $\mathrm{ET}_{\mathrm{A}}$ mRNA $(M)$ is not detected except in the wall of the mesenteric artery (arrowhead) and in the mesoderm of the body wall $(b w), \mathrm{ET}_{\mathrm{B}}$ mRNA $(N)$ is detected in a few cells of the proximal segment of the umbilical loop (thin arrow) and in endothelial cells of the mesenteric artery (arrowhead), but not in the terminal portion of the gut (arrow), whereas ET-3 $(O)$ is highly expressed in both these segments of the distal digestive tube (asterisks in $M-O$ show the lower aorta). Bright-field: $A-C$; dark-field: $D-O$. Scale bars, $A-C, 10 \mu \mathrm{m} ; D-L, 50 \mu \mathrm{m} ; M-O, 100 \mu \mathrm{m}$. 
Table III. mRNA Expression of the Components of the ET System (Stage 15, 16, 17 Human Embryos)

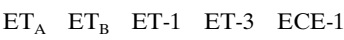

\begin{tabular}{|c|c|c|c|c|c|}
\hline \multicolumn{6}{|l|}{ Axial skeleton: } \\
\hline Dorsal root ganglia & + & + & - & - & - \\
\hline Sympathetic ganglia & + & + & - & - & - \\
\hline Sclerotome & - & - & - & - & - \\
\hline Intervertebral mesenchyme & + & - & - & - & - \\
\hline Sensory nerves (Schwann cells) & - & + & - & - & - \\
\hline \multicolumn{6}{|l|}{ Branchial arches; } \\
\hline 1st and 2nd: mesoderm & + & + & - & + & - \\
\hline epithelium & - & - & - & - & - \\
\hline 3rd to 5th: mesenchyme & + & - & - & - & - \\
\hline epithelium & - & - & - & - & - \\
\hline \multicolumn{6}{|l|}{ Digestive tract: } \\
\hline Pharynx: mesoderm & + & + & - & - & + \\
\hline ganglionic cells & - & + & - & - & - \\
\hline Esophagus: mesoderm & + & + & - & - & + \\
\hline ganglionic cells & - & + & - & - & - \\
\hline Stomach: mesoderm & + & - & - & - & + \\
\hline ganglionic cells & - & + & - & - & - \\
\hline Duodenum: mesoderm & - & - & - & + & + \\
\hline ganglionic cells & - & + & - & - & - \\
\hline Umbilical loop, proximal: mesoderm & - & - & - & + & + \\
\hline ganglionic cells & - & + & - & - & - \\
\hline distal: mesoderm & - & - & - & + & + \\
\hline ganglionic cells & - & - & - & - & - \\
\hline Hindgut: mesoderm & - & - & - & + & + \\
\hline Mesenteric artery: VSMC & + & - & + & - & + \\
\hline endothelium & - & + & + & - & + \\
\hline Pancreas: epithelium & - & - & - & - & + \\
\hline mesoderm & + & - & - & - & + \\
\hline Liver: hepatocytes & - & - & + & + & + \\
\hline sinusoids & + & + & - & - & - \\
\hline \multicolumn{6}{|l|}{ Mesonephros: } \\
\hline Wolffian duct & - & + & - & - & - \\
\hline Proximal tubule & - & - & - & - & + \\
\hline Mesenchyme & + & - & - & - & + \\
\hline Glomeruli (mesangium) & + & - & + & - & + \\
\hline Subepidermal mesenchyme & + & + & - & - & - \\
\hline
\end{tabular}

See Table IV for the cardiovascular system. Same legend as Table II.

pressed in all myocytes (cardiac and vascular), $\mathrm{ET}_{\mathrm{B}}$ mRNA in most endothelial and endocardial cells, ET-1 and ECE-1 in both the myocytes and endothelial cells, and ET-3 was not detected.

Both $\mathrm{ET}_{\mathrm{A}}$ and $\mathrm{ET}_{\mathrm{B}}$ receptor mRNAs were expressed in the digestive tract from the pharynx to the stomach (Fig. 2, $K$ and $L$; see recapitulated observations in Table III), but from there down, and up to the proximal segment of the umbilical loop, only $\mathrm{ET}_{\mathrm{B}}$ was expressed exclusively in ganglionic cells, not in the mesoderm (Fig. 2, $M$ and $N$ ). No $\mathrm{ET}_{\mathrm{B}}$ receptor mRNA was detected in the distal segment of the umbilical loop and the hindgut. ET-1 mRNA was absent from the digestive tube, whereas ET-3 mRNA was observed in the mesoderm from the duodenum to the hindgut (Fig. $2 O$ ), and ECE-1 from the pharynx to the hindgut. In the liver, $\mathrm{ET}_{\mathrm{A}}$ and $\mathrm{ET}_{\mathrm{B}}$ receptor mRNAs were expressed in nonhepatocyte cells, whereas ET-1,
ET-3, and ECE-1 mRNAs were expressed in hepatocytes (not shown).

\section{Discussion}

This study on the human embryo describes the onset and distribution in various tissues of mRNA expression for $\mathrm{ET}_{\mathrm{A}}$ and $\mathrm{ET}_{\mathrm{B}}$ receptors, for prepro-ET-1 and -3 and for ECE- 1 from 3 to $6 \mathrm{wk}$ of gestation (prepro-ET-2 and ECE-2 were not studied). This period encompasses intense and crucial morphogenesis and organogenesis processes: closure of the NT and formation of cephalic vesicles, transformation of the cardiac tube into a four-cavity heart, closure and differentiation of the open digestive tube into esophagus, stomach, duodenum, umbilical loop, and hindgut, building of the entire peripheral nervous system including sensory and autonomous ganglia, and the edification of the axial skeleton. During the same period of development, NC cells appear in the NT, emigrate from the neuroepithelium, and colonize numerous and various target sites throughout the whole embryo. The temporal coincidence between the onset of the ET receptors and the critical period of $\mathrm{NC}$ cell migration, proliferation, and differentiation in tissues and structures, known to derive at least in part from the NC, will be examined in the context of ETs as growth/differentiation factors for NC cells.

ET receptors are not exclusive markers of NC and their derivatives. $\mathrm{ET}_{\mathrm{A}}$ and $\mathrm{ET}_{\mathrm{B}}$ receptor $\mathrm{mRNAs}$ appear first almost simultaneously around stage 9-10 in the neuroepithelium, at the exact location of the cephalic NC. However, at this early stage, cells which do not belong to the $\mathrm{NC}$ lineage also express $\mathrm{ET}_{\mathrm{A}}$ and $\mathrm{ET}_{\mathrm{B}}$ receptor mRNAs. If $\mathrm{ET}_{\mathrm{A}}$ labeled mesenchymal cells in the cephalic region might be considered of NC origin, this is not the case for the epithelium of the foregut diverticulum, the surface epithelium laterally to the neuroepithelium, the endocardium of the primitive heart, or the notochordal plate, all structures which express $\mathrm{ET}_{\mathrm{A}}$ and $\mathrm{ET}_{\mathrm{B}}$ receptor mRNAs. Moreover, stage 9-10 in human development (equivalent approximately to day $8-8.5$ in the rat) corresponds to the very beginning of the cephalic $\mathrm{NC}$ formation and it is unlikely that $\mathrm{NC}$ cells have already migrated so far as the heart. Therefore, al-

Table IV. Expression of mRNA of the ET System Components in the Cardiovascular System (Stage 15, 16, 17 Human Embryos)

\begin{tabular}{|c|c|c|c|c|c|}
\hline & $\mathrm{ET}_{\mathrm{A}}$ & $\mathrm{ET}_{\mathrm{B}}$ & ET-1 & ET-3 & ECE-1 \\
\hline Aortic arches: endothelium & - & + & + & - & + \\
\hline VSMC & + & - & + & - & + \\
\hline Bulbus arteriosus: endothelium & - & - & + & - & + \\
\hline VSMC & + & - & + & - & + \\
\hline Endocardial cushion: endothelium & - & - & + & - & + \\
\hline myocardium & + & - & - & - & + \\
\hline Bulbus cordis: endothelium & - & + & - & - & + \\
\hline trabeculated myocard. & + & - & + & - & - \\
\hline Sinus venosus: endothelium & + & + & + & - & + \\
\hline myocardium & + & - & - & - & - \\
\hline Coronary arteries: endothelium & - & + & + & - & + \\
\hline myocardium & + & - & - & - & + \\
\hline
\end{tabular}

Same legend as Table II. 
ready at the earliest stage of $\mathrm{NC}$ formation within the $\mathrm{NT}, \mathrm{ET}_{\mathrm{A}}$ and $\mathrm{ET}_{\mathrm{B}}$ receptors appear more widely distributed than only the NC cells.

Expression of several ET system components in the same cells and in neighboring cells. Although both $\mathrm{ET}_{\mathrm{A}}$ and $\mathrm{ET}_{\mathrm{B}}$ were not studied in the very same sections, this study suggests the colocalization of $\mathrm{ET}_{\mathrm{A}}$ and $\mathrm{ET}_{\mathrm{B}}$ receptors within the same cells since, from stage 10 onward, on a given section almost all cells in the NC appear labeled for each one of the two receptor probes. As we have hybridized a selection of sections $(\sim 200$ $\mu \mathrm{m}$ apart of each other), which cannot definitively exclude that the two receptors are expressed at different levels along the NT, all our observations, including sagittal sections at later stages, appear to exclude this possibility in stage 10 embryos and later in development. At all stages studied, the distribution of $\mathrm{ET}_{\mathrm{A}}$ receptor mRNA appears more widespread in the embryo than that of $\mathrm{ET}_{\mathrm{B}}$. In addition, $\mathrm{ET}_{\mathrm{A}}$ is often restricted to the mesodermal component of structures and organs, despite its first appearance in $\mathrm{NC}$ within the neuroepithelium at stage 9-10. The tissue distribution of ET-1 and ET-3 mRNA expression is also different: ET-1 is expressed in few well identified and differentiated cells (endothelium and hepatocytes), whereas ET-3 displays a more diffuse pattern of expression in the mesodermal component of the branchial arches and the digestive tract. Assuming that an ECE is also present at the same site to convert big ET-1 or big ET-3 into its active form, and given the respective affinities of $\mathrm{ET}_{\mathrm{A}}$ and $\mathrm{ET}_{\mathrm{B}}$ for ET-1 and ET-3, the colocalization of ET-1 with $\mathrm{ET}_{\mathrm{B}}$ in endothelial cells, of ET-1 with $\mathrm{ET}_{\mathrm{A}}$ in the branchial arches, or of ET-3 with $\mathrm{ET}_{\mathrm{B}}$ in the hindgut may facilitate discriminating effects of ETs which would otherwise appear impossible or not ligand specific, because of the source-target distance and distribution in the whole body of the embryo. For instance, ET-1 produced by endothelial cells can exert autocrine or paracrine effects directly on the same or on neighboring cells through the $\mathrm{ET}_{\mathrm{B}}$ receptor at the surface of these endothelial cells, whereas ET-3 may be prevented from acting on these endothelial cells because of the distance and physical barriers from the main source of ET-3 (the mesoderm of digestive tract and first branchial arch) and the endothelium lining the lumen of blood vessels. The respective distribution patterns of expression of a ligand and of its receptor appear as essential parameters to account for the specificity of the effects, in addition to the respective affinities of the ligands for the receptors.

The existence of such a strictly local mechanism is confirmed by the inability of ET-1 to substitute for the inactive form of ET-3 in $1^{\mathrm{s}}$ mutant mice in inducing the differentiation of the enteric nervous system in the distal part of the gut (10). ET-3 is produced in the mesodermal component of the digestive tract, in cells which completely surround the ganglionic cells. In normal animals these latter cells express $\mathrm{ET}_{\mathrm{B}}$ receptor mRNA and are directly exposed to ET-3 produced in neighboring mesodermal cells. If ET-3 is defective, as in $1^{\mathrm{s}}$ mutant mice, even though ET-1 is produced in the mesenteric artery, a sufficient concentration of this ligand does not reach the dense mesodermal compartment, where ganglionic cells migrate, to induce a normal colonic gangliogenesis. The hormonal effect of ET-1 cannot substitute for the deficient local effect of ET-3.

Spatiotemporal pattern of expression of the ET system components. The causative role played by ET-3 and its $\mathrm{ET}_{\mathrm{B}}$ receptor in some cases of Hirschsprung's disease (13-18), in $\mathrm{s}^{1}$ and in $1^{\mathrm{s}}$ mutant mice $(10,12)$, and in the experimental models re- producing the same phenotype $(10,12)$ raises the question of the sources and targets of the ligands. Consequently, several recent articles have underlined the need to answer these questions in order to explain the phenotypes observed and clarify the involvement of ETs on NC cell differentiation $(22,29,30)$. Our observations of the spatiotemporal pattern of expression of the ET system components in the digestive tract, cardiovascular system, nervous system, and axial skeleton during the critical period of $\mathrm{NC}$ cell migration constitute a decisive step toward answering these questions. For instance, in the digestive tract, $\mathrm{ET}_{\mathrm{A}}$ and $\mathrm{ET}_{\mathrm{B}}$ receptor $\mathrm{mRNA}$ are expressed in the mesoderm of the anterior part of the digestive tube $\left(\mathrm{ET}_{\mathrm{A}}\right.$ from pharynx to stomach and $\mathrm{ET}_{\mathrm{B}}$ from pharynx to esophagus). $\mathrm{ET}_{\mathrm{B}}$ is also expressed in the digestive tube but in ganglionic cells (identified by tyrosine hydroxylase immunostaining) along the digestive tube up to the umbilical loop with a distribution comparable to that of $\mathrm{ET}_{\mathrm{B}}$ mRNA in the chick embryo (22). It is most likely that the oldest embryos observed in this study (stage 17) were too young to display the complete colonization of the whole gut, and therefore they may be at the exact stage when the digestive tube colonization by ganglionic cells is arrested in Hirschsprung's disease and in cognate mutant mice.

The ligands are also simultaneously expressed in the digestive tract: ET-1 in the endothelium and smooth muscle cells of the mesenteric artery, and ET-3 in the mesoderm from the duodenum to the hindgut. Since ECE-1 is also expressed in the same mesodermal cells as ET-3, active ET-3 can be produced there. From these observations we propose the following explanation for the absence of ganglionic cells in the distal part of the hindgut consecutively to an ineffective ET-3/ET $\mathrm{ET}_{\mathrm{B}}$ interaction. ETs are not essential to the migration, colonization, and differentiation of ganglionic cells in the foregut up to a point between the duodenum and the proximal segment of the umbilical loop, since this part of the digestive tube is normally colonized by NC cells in ET-3/ET ${ }_{\mathrm{B}}$ defective individuals (10$12,30)$. In contrast, in the distal part of the digestive tube, ganglionic cells must be instructed by ET-3, produced by mesodermal cells, to continue to proliferate and delay their differentiation until they have colonized the most distal part of the digestive tube. In cases of defective ET-3 or $\mathrm{ET}_{\mathrm{B}}$ genes, ganglionic cells colonize the stomach, the duodenum, and midgut, but in the absence of a specific signal induced by $\mathrm{ET}_{\mathrm{B}}$ activation, stop proliferating, begin their functional differentiation, and do not reach the terminal part of the hindgut. As a consequence, the colon remains aganglionic as in the different models of megacolon linked to a neurocristopathy.

ET and melanoblast differentiation. The other major abnormality of the ET-3/ET $\mathrm{ET}_{\mathrm{B}}$ mutation is a spotted or a complete lack of pigmentation. The initial cause of this defect has been shown to occur shortly after NC cells leave the NT (31) and could be explained by a process quite similar to that proposed above for the agangliogenesis (8): in cultured NC cells ET-3 delays melanocyte differentiation and stimulates proliferation. In normal development, this proliferative effect would produce a sufficient number of melanoblasts to colonize the whole surface of the body. However, in a more recent paper by the same group (22) it was found that melanocytes do not express $\mathrm{ET}_{\mathrm{B}}$ receptor mRNA. In addition, Reid et al. (9), using cultured NC cells from mouse embryos, showed that the ET-3/ $\mathrm{ET}_{\mathrm{B}}$ interaction caused successively proliferation and differentiation of melanocyte progenitor cells. The results reported in this study confirm the lack of $\mathrm{ET}_{\mathrm{B}}$ expression in melanoblasts 
once they are topographically distinct from the other NC lineages. Indeed, we demonstrate that $\mathrm{ET}_{\mathrm{A}}$ and $\mathrm{ET}_{\mathrm{B}}$ receptor mRNAs are both present in NC cells as they leave the neuroepithelium and form strands of cells along the neural axis, and until these cells part into two topographically distinct subpopulations which follow either the lateral or the ventromedial pathway. Then, respectively, they stop $\mathrm{ET}_{\mathrm{B}}$ expression and constitute the melanocyte progenitor population, or stop $\mathrm{ET}_{\mathrm{A}}$ expression and form mesectodermal and neural derivatives, including the ganglionic cells of the enteric nervous system. Thus, at least in the human, the $\mathrm{ET}_{\mathrm{B}}$ receptor present in the normal development mediates the proliferative effect of ET-3 on melanoblasts as on enteric ganglionic cells. The defective ET-3 or $\mathrm{ET}_{\mathrm{B}}$ genes can explain the two major signs (skin pigmentation and enteric gangliogenesis) of Hirschsprung's disease and related mutant mice models. Both defects may be caused at two different stages of development by the lack of the same ET-3/ET $\mathrm{B}_{\mathrm{B}}$ mediated signal, thus leading to a too precocious differentiation of melanocytes or ganglionic cells before they have completely populated their predetermined territory. In this unified model, ETs could have a repressive effect on differentiation or more probably a stimulating effect on proliferation, thus indirectly delaying differentiation. However, if there is actually a source of ET-3 to activate $\mathrm{ET}_{\mathrm{B}}$ receptor in the gut, we did not detect either ET-1 or ET-3 mRNA in the close vicinity of the $\mathrm{NC}$ at the early stage of melanocyte migration. One has to postulate the production of ETs by the somites or the surface epithelium. Another possibility, which has been overlooked in this study as in others, is the putative role of ET-2, whose affinity is comparable for the two receptor types.

ETs and cardiogenesis. The heart tube and branchial arches are one of the important sites of ET receptors expression early in development. $\mathrm{ET}_{\mathrm{A}}$ receptor transcripts are detected in the myocardia when it is composed of a few layers of cells and $\mathrm{ET}_{\mathrm{B}}$ receptor transcripts are present at the same stage in the mesocardia. Later in development (stages 15 to 17 ), $\mathrm{ET}_{\mathrm{A}}$ mRNA is highly expressed in peripheral mesoderm of branchial arches. In comparison, $\mathrm{ET}_{\mathrm{B}} \mathrm{mRNA}$ is restricted to a single cluster of cells, more or less central in arches 1 and 2. In the heart itself, all components of the ET system are present and allow us to envisage different possible interactions to explain the malformations observed in ET-1 deficient mutant mice (19, 20). ET-1 may have mitogenic effects on cardiomyocytes and vascular smooth muscle cells through the $\mathrm{ET}_{\mathrm{A}}$ receptor and on endocardial cells through the $\mathrm{ET}_{\mathrm{B}}$ receptor. Both tissues contribute to the closure of the interventricular septum and to the formation of the inflow and outflow tract vessels of the heart.

Therefore, it appears that, as an ET-3/ET $\mathrm{ET}_{\mathrm{B}}$ interaction is involved in the colonic gangliogenesis, an ET-1/ET $\mathrm{A}_{\mathrm{A}}$ dependent mechanism may account for the consequences of ET-1 inactivation since we have observed a high level of $\mathrm{ET}_{\mathrm{A}}$ receptor transcripts in all mesodermal cells surrounding the arches, epithelium, and branchial arteries, and an expression of ET-1 mRNA in the branchial arches (mesoderm and epithelium). ET-1 mRNA is also detected in endothelial and smooth muscle cells of the branchial arteries. When this ET-1/ET $\mathrm{A}_{\mathrm{A}}$ system is ineffective, malformations occur probably due to altered proliferation and premature differentiation before all structures (cartilage, blood vessels, heart cavities) undergo their final functional differentiation. The full phenotype obtained, which is quite similar to that of the Pierre-Robin and other congenital syndromes (19), is characterized by craniofacial and cardiovascular malformations due to impaired branchial arch differentiation.

ETs and NT. ET receptor mRNAs are expressed at high levels in the NT. The expression of $\mathrm{ET}_{\mathrm{B}}$ mRNA greatly surpasses that of $\mathrm{ET}_{\mathrm{A}}$ for the number of positive cells. With the exception of the youngest stages studied (stage 10 and younger), when both $\mathrm{ET}_{\mathrm{B}}$ transcripts are detected in $\mathrm{NC}$ within the neuroepithelium, only cells closest to the ependymal canal express $\mathrm{ET}_{\mathrm{B}}$ receptor mRNA. All the positive cells for $\mathrm{ET}_{\mathrm{A}}$ or $\mathrm{ET}_{\mathrm{B}}$ belong to the ependymal layer, whereas cells of the mantle layer and floor plate are completely devoid of receptor mRNAs. The mantle layer is the site where the first neurons differentiate, and the floor plate is involved in complicated and only partially understood interactions between the notochord and the NT. However, if $\mathrm{ET}_{\mathrm{B}}$ is to mediate any effects of ETs on the NT, the hormonal signal must be produced locally. Since neither ET-1 nor ET-3 mRNA is detected locally, one might consider for these effects the possible role of ET-2. This points to the involvement of the $\mathrm{ET}_{\mathrm{B}}$ receptor in the neuronal-glial lineage separation which occurs as cells of the NT undergo mitosis (32). The exact source and nature of the ligand which triggers this fundamental differentiation process remains to be investigated.

Conclusion. The observations reported here show how ETs may exert critical roles in NC derived cell migration, proliferation, and differentiation, and how a defective ligand or receptor may account for the phenotypes of some neurocristopathies. This study constitutes the basis to understand some of the cellular interactions in which ETs are involved and which allow NC cells to multiply, migrate, and arrest at their destination, and to differentiate.

Finally, the expression of the ET receptors very early in human embryonic development, at a stage when pregnancy may not yet be known, points out the danger of artificially blocking or activating ET receptors during early pregnancy. Because of their potentially teratogenic effects, ET agonists and antagonists must not be used in women who are or who may become pregnant. These results appear as a timely warning when ET analogues, owing to their multifaceted effects, are the subject of numerous physiological studies aimed at applications in the human, and are being investigated in preliminary clinical trials.

\section{Acknowledgments}

The authors thank Dr. E. Aubeny for help in obtaining the human embryos, S. Schütz for preparation of the human embryos, M.-T. Morin and F. Mongiat for excellent technical assistance, and Dr. Olivier Valdenaire and Petra Korth for the gift and subcloning of the ET-1 and ET-3 cDNAs.

\section{References}

1. Yanagisawa, N., H. Kurihara, S. Kimura, Y. Tomobe, M. Kobayashi, Y. Mitsui, Y. Yazaki, K. Goto, and T. Masaki. 1988. A novel vasoconstrictor peptide produced by vascular endothelial cells. Nature. 332:411-415.

2. Levin, E.R. 1995. Endothelins. N. Engl. J. Med. 333:356-363.

3. Rubanyi, G.M., and M.A. Polokoff. 1994. Endothelins: molecular biology, biochemistry, pharmacology, physiology, and pathophysiology. Pharmacol. Rev. 46:325-415.

4. Ziche, M., L. Morbidelli, S. Donnini, and F. Ledda. 1995. ETB receptors promote proliferation and migration of endothelial cells. J. Cardiovasc. Pharmacol. 26 (Suppl. 3):S284-S286.

5. Fukuda, K., T. Yanagida, S. Okuda, K. Tamaki, T. Ando, and M. Fujishima 1996. Role of endothelin as a mitogen in experimental glomerulonephritis in 
rats. Kidney Int. 49:1320-1329.

6. Bagnato, A., R. Tecce, V. Di Castro, and K.J. Catt. 1997. Activation of mitogenic signaling by endothelin 1 in ovarian carcinoma cells. Cancer Res. 57: $1306-1311$.

7. Sugawara, F., H. Ninomiya, Y. Okamoto, S. Miwa, O. Mazda, Y. Katsura, and T. Masaki. 1996. Endothelin-1-induced mitogenic responses of Chinese hamster ovary cells expressing human endothelin A: the role of a wortmanninsensitive signaling pathway. Mol. Pharmacol. 49:447-457.

8. Lahav, R., C. Ziller, E. Dupin, and N.M. Ledouarin. 1996. Endothelin 3 promotes neural crest cell proliferation and mediates a vast increase in melanocyte number in culture. Proc. Natl. Acad. Sci. USA. 93:3892-3897.

9. Reid, K., A.M. Turnley, G.D. Maxwell, Y. Kurihara, H. Kurihara, P.F. Bartlett, and M. Murphy. 1996. Multiple roles for endothelin in melanocyte development: regulation of progenitor number and stimulation of differentiation. Development. 122:3911-3919.

10. Greenstein Baynash, A.G., K. Hosoda, K. Giaid, J.A. Richardson, N. Emoto, R.E. Hammer, and M. Yanagisawa. 1994. Interaction of endothelin-3 with endothelin-B receptor is essential for development of epidermal melanocytes and enteric neurons. Cell. 79:1277-1285.

11. Gariepy, C.E., D.T. Cass, and M. Yanagisawa. 1996. Null mutation of endothelin receptor type B gene in spotting lethal rats causes aganglionic megacolon and white coat color. Proc. Natl. Acad. Sci. USA. 93:867-872.

12. Hosoda, K., R.E. Hammer, J.A. Richardson, A.G. Baynash, J.C. Cheung, A. Giaid, and M. Yanagisawa. 1994. Targeted and natural (Piebaldlethal) mutations of endothelin-B receptor gene produce megacolon associated with spotted coat color in mice. Cell. 79:1267-1276.

13. Attie, T., M. Till, A. Pelet, J. Amiel, P. Edery, L. Boutrand, A. Munnich, and S. Lyonnet. 1995. Mutation of the endothelin-receptor B gene in Waardenburg-Hirschsprung disease. Hum. Mol. Genet. 4:2407-2409.

14. Auricchio, A., G. Casari, A. Staiano, and A. Ballabio. 1996. Endothelin-B receptor mutations in patients with isolated Hirschsprung disease from a noninbred population. Hum. Mol. Genet. 5:351-354.

15. Hofstra, R.M.W., J. Osinga, G. Tansindhunata, Y. Wu, E.J. Kamsteeg, R.P. Stulp, C. Vanravenswaaijarts, D. Majoorkrakauer, M. Angrist, A. Chakravarti, C. Meijers, and C.H.C.M. Buys. 1996. A homozygous mutation in the endothelin-3 gene associated with a combined Waardenburg type 2 and Hirschsprung phenotype (Shah-Waardenburg syndrome). Nat. Genet. 12:445-447.

16. Edery, P., T. Attie, J. Amiel, A. Pelet, C. Eng, R.M. Hofstra, H. Martelli, C. Bidaud, A. Munnich, and S. Lyonnet. 1996. Mutation of the endothelin-3 gene in the Waardenburg-Hirschsprung disease (Shah-Waardenburg syndrome). Nat. Genet. 12:442-444.

17. Kusafuka, T., and P. Puri. 1997. Mutations of the endothelin-B receptor and endothelin-3 genes in Hirschsprung's disease. Pediatr. Surg. Int. 12:19-23.

18. Puffenberger, E.G., H. Kiminori, S.S. Washington, K. Nakao, D. de Wit, M. Yanagisawa, and A. Chakravarti. 1994. A missense mutation of the endothelin-B receptor gene in multigenic Hirschsprung's disease. Cell. 79:1257-1266.

19. Kurihara, Y., H. Kurihara, H. Oda, K. Maemura, R. Nagai, T. Ishikawa, and Y. Yazaki. 1995. Aortic arch malformations and ventricular septal defect in mice deficient in endothelin-1. J. Clin. Invest. 96:293-300.

20. Kurihara, Y., H. Kurihara, H. Suzuki, T. Kodama, K. Maemura, N. Nagai, H. Odai, T. Kuwaki, W.H. Cao, N. Kamada, et al. 1994. Elevated blood pressure and craniofacial abnormalities in mice deficient in endothelin-1. $\mathrm{Na}$ ture. 368:703-710.

21. Kapur, R.P., D.A. Sweetser, B. Doggett, J.R. Siebert, and R.D. Pal- miter. 1995. Intercellular signals downstream of endothelin receptor-B mediate colonization of the large intestine by enteric neuroblasts. Development. 121 $3787-3795$.

22. Nataf, V., L. Lecoin, A. Eichmann, and N.M. Le Douarin. 1996. Endothelin-B receptor is expressed by neural crest cells in the avian embryo. Proc. Natl. Acad. Sci. USA. 93:9645-9650.

23. Chan, T.S., C.X. Lin, W.Y. Chan, S.S. Chung, and S.K. Chung. 1995 Mouse preproendothelin-1 gene. cDNA cloning, sequence analysis and determination of sites of expression during embryonic development. Eur. J. Biochem. 234:819-826.

24. MacCumber, M.W., C.A. Ross, B.M. Glaser, and S.H. Snyder. 1989. Endothelin: visualization of mRNAs by in situ hybridization provides evidence for local action. Proc. Natl. Acad. Sci. USA. 86:7285-7289.

25. Sibony, M., F. Commo, P. Callard, and J.M. Gasc. 1995. Enhancement of mRNA in situ hybridization signal by microwave heating. Lab. Invest. 73 : $586-591$.

26. Schutz, S., J.M. Le Moullec, P. Corvol, and J.M. Gasc. 1996. Early expression of all the components of the renin-angiotensin-system in human development. Am. J. Pathol. 149:2067-2079.

27. O'Rahilly, R., and F. Müller. 1987. Developmental Stages in Human Embryos. Carnegie Institution of Washington Publication. 637.

28. Valdenaire, O., E. Rohrbacher, and M.G. Mattei. 1995. Organization of the gene encoding the human endothelin-converting enzyme (ECE-1). J. Biol. Chem. 270:29794-29798.

29. Gershon, M.D. 1997. Genes and lineages in the formation of the enteric nervous system. Curr. Opin. Neurobiol. 7:101-109.

30. Kapur, R.P., R. Livingston, B. Doggett, D.A. Sweetser, J.R. Siebert, and R.D. Palmiter. 1996. Abnormal microenvironmental signals underlie intestinal aganglionosis in dominant megacolon mutant mice. Dev. Biol. 174:360-369.

31. Pavan, W.J., and S.M. Tilghman. 1994. Piebald lethal (sl) acts early to disrupt the development of neural crest-derived melanocytes. Proc. Natl. Acad. Sci. USA. 91:7159-7163.

32. Chenn, A., and S.K. McConnell. 1995. Cleavage orientation and the asymmetric inheritance of Notch1 immunoreactivity in mammalian neurogenesis. Cell. 82:631-641.

33. Hosoda, K., K. Nakao, A. Hiroshi, S. Suga, Y. Ogawa, M. Mukoyama, G. Shirakami, Y. Saito, S. Nakanishi, and H. Imura. 1991. Cloning and expression of human endothelin-1 receptor cDNA. FEBS Lett. 287:23-26.

34. Itoh, Y., M. Yanagisawa, S. Ohkubo, C. Kimura, T. Kosaka, A. Inoue, N. Ishida, Y. Mitsui, H. Onda, M. Fujino, et al. 1988. Cloning and sequence analysis of cDNA encoding the precursor of a human endothelium-derived vasoconstrictor peptide, endothelin: identity of human and porcine endothelin. FEBS Lett. 231:440-444.

35. Onda, H., S. Ohkubo, K. Ogi, T. Kosaka, C. Kimura, H. Matsumoto, N. Suzuki, and M. Fujino. 1990. One of the endothelin gene family, endothelin 3 gene, is expressed in the placenta. FEBS Lett. 261:327-330.

36. Sakamoto, A., M. Yanagisawa, T. Sakurai, Y. Takuwa, H. Yanagisawa, and T. Masaki. 1991. Cloning and functional expression of human cDNA for the ETB endothelin receptor. Biochem. Biophys. Res. Commun. 178:656-663.

37. Shimada, K., Y. Matsushita, K. Wakabayashi, M. Takahashi, A. Matsubara, Y. Iijima, and K. Tanzawa. 1995. Cloning and functional expression of human endothelin converting enzyme cDNA. Biochem. Biophys. Res. Commun. 207:807-812. 